\title{
The Effect of Survey, Connection, Read, Outline and Look Back (SCROL) Strategy to Increase Students' Reading Comprehension of Descriptive Text in Tenth Grade of MAN 1 Takengon
}

\section{Linda Fitri Ibrahim}

Institut Agama Islam Negeri Takengon, Indonesia

lindaraffasya6@gmail.com

\section{Abstract}

The purpose of this research is: "To know whether Survey, Connection, Read, Outline and Look Back (SCROL) strategy significantly affect to increase students' reading comprehension of descriptive at tenth grade of MAN 1 Takengon". The method used in this research is quantitative research with an experiment approach. For collecting data are using observation and test. The population in this research is the tenth grade students of MAN 1 Takengon with total number 221 students. Sample used in this research is X Scince 2 class as the experimental class and the control class X Science1. Both of the class consist of 20 students. The result of this research based on calculation of $t$-test, where the value of tscore 3,8 is higher than ttable 1,9 at the level significance 0,05. It shows that the hypothesis ( $\mathrm{Ha})$ is accepted and the research hypothesis (Ho) is rejected. Based on the results, for suggestion teacher can apply this method in teaching reading and using appropriate technique in teaching and the learning process.
Keywords

SCROLstrategy, reading

comprehension;

descriptive text

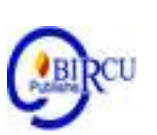

\section{Introduction}

Reading is the process to understand a written text which means extracting the acquired information from it as efficiently as possible. It means that the reader should be able to manage every part of the text, because it is easy to comprehend the information submitted on the text and by reading, the reader get more knowledge as they are able to comprehend and construct the meaning of the text. According to Harmer (2000: 199) reading comprehension is a receptive skill and then receptive skill is the ways to people to gathering meaning from the discourse or the text that have read. It can be said that reading comprehension is a skill where the reader do not just read the text, but its more than read. It is the way to get understanding the concept from the writer and gathering information from the text, it is not only on the pronouncing or loud reading, but also on the understanding the text about and can get the information and writer massage in the text.

In reality, it was found that almost students have some problems in reading comprehension. Reading is a necessary skill that any learners needs. Unfortunately, how to teaching reading has not given due care in the school. The result in such case, the students are lack motivation to read, even if they read they show negative attitudes such as they are not interest to reading. These situations were caused by several factors; it can be from students' internal and external factors. The students' internal factor such as age, intelligence, ability, learning style, interest, attitude, motivation, self-efficacy and other factors. The external factor such as teacher, environment, material, strategy and others. 
There are many instructional strategies which can be applied in teaching reading. In this research the researcher raise one of strategy that have been done successfully by some linguist experts to be applied to increase students' reading achievement in developed country, that is SCROL strategy. This is a reading comprehension strategy designed for students to help them to read and understand text books and a variety of source books, the strategy encourages students to use text headings to aid students' comprehension and help them find and remember important information.

\section{Review of Literatures}

\subsection{Reading}

\section{a. The Nature of Reading}

According to Nunan (1986: 33) reading is viewed as a process of decoding written symbol or sign, working from smaller unit to largers. In the other word, reading use strategies to decode written forms in order to arrive at meaning. It means that reading as the process of communicating between the reading text and reader who using strategies.

Furthermore Patel and Praven (2008: 113) stated that reading means to understanding the meaning of printed word i.e written symbols. Reading is an active process which consists of recognition and comprehension skill. It means that recognition and comprehension skill are the ability to process text, understand the meaning, and to intergrate with the reader already know. Ability to comprehend text is influenced by readers' skill and their ability to process information, if word recognition is difficult students use too much of their processing capacity to read individual word, which interferes with their ability to comprehend what is their read. So, recognition and comprehension is an important part from reading to enlarge reader knowledge.

In addition, Susan (2003: 91) said that:

"Reading plays a particularly important role in education. Not only does education system demand a lot of reading in the process of learning, it also tends to use the capacity to read fluently as an indicator of more general intellectual ability. This tendency to asses intelect through reading is misplaced but prevalent and therefore cannot be ignored. It is part of the function ascribed to literacy, albeit on we need to resist and reform."

From the explanation above it is clearly that reading is plays an important role in teaching. In education a lot of learning process using reading. Reading as a basic from more general intelectual skill who had had by students'. So, in this point of view learning on reading is seen important aspect that should be done. Finaly, reading can define as the relationship between the reader and written source.

\section{b. The Purpose of Reading}

In reading activity, teacher and students catch the material in the process of direct communication. It means that one function of reading has been fulfilled. The reader categories out what is simply enabling from what is wished to take as a permanent addition to his domain of understanding and capability. It can be said that the actual purpose in reading is not humbly to occupy in a communication but to develop from this communication to smoothing which endures or spreads the reader conceptual word. The readers should have a skill and understanding from field or sector who they want to dominate.

Rivers and Temperley suggest that second language learners will wants to read for the following purpose: 
1) To obtain the information for some purpose or because we are curious about some topic

2) To obtain instruction on how to perform some task for our work

3) or daily life

4) To act in a play, play a game, do a puzzle

5) To keep in touch with friends by correspondence or to understand business letters

6) To know when or where something will take place or what is available.

7) To know what is happening or has happened

8) For enjoyment or excitemen

\subsection{Reading Comprehension}

\section{a. The Nature of Reading Comprehension}

Comprehension is the active process of construction meaning from text; it involves accesing previous knowledge, undertanding vocabulary and concepts, making inferences and linking key ideas (Vaughn et al, 2004: 98) It means that comprehension is the activity from the reader to take the meaning from text.

In addition, Westwood (2001: 10) state that:

"Reading comprehension has been described as a complex intellectual process involving a number of abilities. Readers must use information already acquired to filter, interpret, organize, reflect upon and established relationship with the new incoming information on the page. In order to understand text, a reader must be able to identify word rapidly, know the meaning of almost all of the words, and be able to combine units of meaning into a coherent message. Understanding of text results from an interaction between word identification, prior knowledge and the effective use of cognitive strategies."

Furthermore, Nunan (1989: 32) states that reading comprehension is actually works in the reverse order from that proposed by the bottom-up approach. In other word, that we need to comprehend meanings in order to identify word and that we generally need to identify words in order to identify letters. It can be said that to understand a text the readers have to read the text with bottom-up approach.

Bottom-up approach means that for taking the meaning from text the reader have to recognize and identify the information from the smallest unit from a passage (letters, morphemes, syllables, words, phrase, sentence, paragraph until text). It means that from a paragraph to the sentence until to the letters. It can be said that reading is a very complex activity that actually do by the readers. After that, reading is a tool that merging all the knowledge from the reader with the information from the text. It commonly content the reader emotion, moods, interesting and much another sendory aspect that purposed to find out the new information from the purpose of reading. Then, the reader should read the text frequently and the reader have to combine the meaning from one sentence with the other santence to find out the meaning from the text. So, comprehension means that the reader have to undertand and can take the massage from the text with correctly. Furthermore, comprehension uses a knowledge, understanding vocabulary, grammar and the information from source to find the main idea from the text. 


\section{b. Strategies for Reading Comprehension}

According to Brown (2001: 306) there are some strategies that can apply in the classroom reading comprehension, as follows:

1) Identify the purpose in reading.

Efficient reading consists of clearly identifying the purpose in reading something. By doing so, the reader know what you are looking for and can weed withour potential distracting information.

2) Use grapheme rules and patterns to aid in bottom-up decoding.

These and multitude of other phonics approaches to reading can prove usefull for learners at the beginning level and especially useful for teaching children and no-literate adults.

3) Use efficient silent reading techniques for relatively rapid comprehension.

Reading speed is usually not much of an issue for all but the most advanced learners. Academic reading, for example, is something most learners manage to accomplish by allocating whatever time they personaly need in order to complete the material.

4) Skim the text for main idea.

Skimming consists of quickly running ones' eyes across a whole text such as an essay, article, or chapter for its gist. Skimming gives readers the advantages of being able to predict the purpose of the passage, the main topic, or massage, and possibly some of the developing or supporting ideas.

5) Scan the text for specific information.

Scanning exercises may ask students to look for names or dates, to find a defintion of a key concept, or to list a certain number of supporting details. The purposes of scanning is to extract specific information without reading throught the whole text.

6) Use semantic mapping or clustering.

The strategy of semantic mapping, or grouping ideas in to meaningful clusters. Making such semantic map can be done individually, but they make for productive group work technique as students collectively induc order and hirarchy to a passage.

7) Guess when reader are not certain.

A gueesing game of sorts, and sooner learners understand this game, the better off they are. The key to successful guessing is to make it reasonbly acurate.

8) Analyze vocabulary.

One way for learners to making guessing pay off when they do not immediately recognice a word is to analyze it interm of what they know about it.

9) Distinguish between literal and impliedd meaning.

This require application of sophiscated top-down processing skill. The fact that not all language can be interpreted appropriately by attending to its literal, syntactic surface structure make special demands on readers.

10) Capitalize on discourse markers to process relationship.

Many discourse makers in English signal relationship among ideas as expressed through phrase, clause, and sentences. A clear comprehension of such markers can greatly and hance learner reading efficiency.

\subsection{SCROL Strategy}

\section{a. The Nature of SCROL Strategy}

SCROL is stand for 'Survey, Connection, Read, Outline and Look back'. Reid (2006: 50) assert that SCROL is a reading comprehension strategy that designed for students to help them to read and understand textbooks and a variety of source books, this strategy 
encourages students to use text headings to aid their comprehension and help them find and remember important information.

Prior to teaching the strategy, it is necessary to evaluate the students' background knowledge. Formal or informal assessments can be used to determine what knowledge and skills the students process and what skills they lack, doing a task breakdown will provide the information for identifying the knowledge and skills necessary to successfully complete the strategy. Students need to understand and remember information that they read in a variety of source books. This helps students understand when, where, and why to use strategy. It is also necessary to point out the obvious problems that could arise if they were not accurate in reading certain texts.

The teacher and students can work together and practices using the strategy until the students are able to perform the strategy fluently and independently. This is a critical part of the strategy instruction process, students need to be given adequate time and support to master strategy. In addition, Grant (2000: 2) explains that SCROL as a strategic training for using text headings to improve students' processing of content. This is a reading comprehension strategy for students in middle and upper grade to help them enable to read the text.

\section{b. The Procedure of SCROL Strategy}

Reid (2006: 50) stated that there are five procedure of SCROL strategy, as follow:

1) Survey

First, the students are instructed to survey chapter headings. This provides students with an idea of what the chapter will be about and prompts them to think about what they already know about the subject, thus activating their prior knowledge of the subject. It also allows them to predict information that the writer may present.

2) Connection

The students ask themselves how the headings relate to one another and write down any keywords from the headings that might provide connection between them.

3) Read

Students read the text and looking for words and phrases that expresses important information about the headings. They can mark the text and make sure if they understand the major ideas and supporting details.

4) Outlines

Students outline the text using identifications to reflect text structure. Students are asked to write the heading and try to outline each heading segment without looking back at the text.

5) Look back

Finally, the students are prompted to look back at the text and check the accuracy of the major ideas and details they write down and correct any inaccurate information in their outline.

\subsection{Descriptive Text}

a. The Nature of Descriptive Text

According to Anderson and Anderson (2003:26) descriptive text describes particular person, place, or things. In addition, according to Pardiyono (2007:33) descriptive text gives descriptions from the living or non-living things to the reader. 


\section{b. The Generic Structure of Descriptive Text}

According Emirfan (2011: 176) the generic structure of descriptive text, as follow:

1) Identification: identifies phenomenon to be described.

2) Description of features: describes parts, qualities, characteristics. It has language features; focus on specific rather than generic participants, use of simple present tense, verb being and having, use of descriptive adjectives to build up long nominal groups.

\section{c. The Language Features of Descriptive Text}

According to Yudantoro (2010: 21) the language features of the descriptive text as follow:

1) Present tense, example borobudur is well-known all over the world, and so on.

2) Detailed noun phrase that is complete in one pharse, usually describes the subject or the object instance it was a large open door.

3) Adjective phrase as two strong legs, sharp white fangs, eat and so on.

4) Verb that serves to explain the information about the subject, for example, my mother is cool; it haas very thick fur and so on.

5) Thinking or feeling verbs or verbs that reflect mental work/ thinking, for example, belive, think, and so on.

6) Action verbs or verb do the real work, example the bites, nake and so on

7) Adverbials e.g. as fast, as the tree house and so on.

8) Figurative language, eg. John is white as chalk, sat tight and so on.

\section{Research Methods}

\subsection{Research Approach}

This research use quantitative methodology. Quantitative is a method of research that based on positivism philosophy, quantitative approach is process collecting data using statistic formula and number of specific data (Arikunto, 2006: 12). It means that quantitative approach is the way for researcher to interpretation and collecting data from the research by using statistic or number.

John W. Creswell (2002: 18) stated that:

"Quantitative approach is one in which investigator primarily uses post positivist claims for developing knowledge (i.e, cause and effect thinking, reduction to specific variables and hypothesis and questions, use of measurement and observation, and the test theories), employs strategies of inquiry such as experiments and surveys and collecting data on pre-determinate instruments that yield statistical data".

Quantitative research is purposed to find out the effect of treatment in both experimental and control groups. It means that a quantitative approach is always using at the entire sample, it is control class and experiment class. But the treatment only used in the experiment class for find out the result of research. 


\subsection{Population and Sample}

\section{a. Population}

Population in this researches all of the students at tenth grade in MAN 1 Takengon with total number 221 students.

Table 1. Population

\begin{tabular}{ccccc}
\hline No & Class & Male & Female & Total \\
\hline 1 & $\mathrm{X}^{\mathrm{a}}$ & 10 & 21 & 31 \\
\hline 2 & $\mathrm{X}^{\mathrm{b}}$ & 17 & 15 & 32 \\
\hline Total & & 27 & 36 & 63 \\
\hline
\end{tabular}

\section{b. Sample}

Ary (2002: 427) stated that sample is a part of population or the representation of a population. The method of sampling in this research is random sampling. The researcher will take the sample order to teach reading use SCROL strategy at tenth grade of MAN 1 Takengon with the total number of students is 40 students' with 20 students' in control class and 20 students' in experiment class.

\subsection{Technique and Instrument of Data Collection}

Techniques of data collection in this research there are observation and test.

\section{a. Observation}

An observation is the act of a human being of receiving knowledge from the outside world by the use of the senses. It is the ability to novice and record happenings or the way a person looks at things.

b. Test

In collecting data, the researcher use t-test to know students growth in reading skill. In this research, assessment will be doing to get the effective strategy in teaching reading and help the teacher more effectively by the better strategy. Furthermore, the result are used to see whether improvements after the actions or not

1) Pre-test

In this test, the researcher gives the pre-test. The researcher has designed the items for reading test depends on the text who will be given by the researcher before the pre-test begins.

2) Post-test

The last step the researcher provide post-test for both classes. Post-test done after applied treatment.

\subsection{Validity and Reliability Test}

a. Validity Test

Validity is a unit of measurement that indicates the level of validity or an instrument's awareness. An instrument is called to be valid if the instrument used can measure what it wants to measure.

To calculate the validity, the researcher will be use the formula as follows:

$$
\mathrm{R}_{\mathrm{xy}}=\frac{\mathrm{N}\left(\sum \mathrm{XY}\right)-\left(\sum \mathrm{X}\right)\left(\sum \mathrm{Y}\right)}{\sqrt{\left\{\mathrm{N}\left(\sum \mathrm{X}^{2}\right)-\left(\sum \mathrm{X}\right)^{2}\right\}\left\{\mathrm{N}\left(\sum \mathrm{Y}^{2}\right)-\left(\sum \mathrm{Y}\right)^{2}\right\}}}
$$


Where:

$\mathrm{R}_{\mathrm{xy}}=$ The correlation of the scores on two halves of the test

$\mathrm{N}=$ The number of the students in each group

$\mathrm{X}=$ The score of each component of writing scoring

$\mathrm{Y}=$ The sum of all dialogues score

$\sum \mathrm{x}=$ The sum of total $\mathrm{x}$ score in each group

$\sum \mathrm{y}=$ The sum of total score from each student

$\sum x y=$ The sum of multiple score from each student with the total score.

$\sum \mathrm{x}^{2}=$ The sum of the square score in each writing component

$\sum \mathrm{y}^{2}=$ The sum of all dialogues score square

\section{b. Reliability Test}

The reliability of an instrument is the consistent measurement result of the measurement. Therefore it is very necessary to know the reliability before use.

To calculate the reliability of the test, the researcher used the formula as follows:

$$
\mathrm{r}_{11}=\frac{(\mathrm{n})}{(\mathrm{n}-1)} \quad \frac{\left(1-\sum \mathrm{S}_{\mathrm{i}}^{2}\right)}{\left(\mathrm{S}_{\mathrm{t}}^{2}\right)}
$$

Where:

$\mathrm{r}_{11} \quad=$ Index reliability

$\sum \mathrm{S}_{\mathrm{i}}^{2} \quad=$ Item variance

$\mathrm{S}_{\mathrm{t}}^{2} \quad=$ Total variance

$\mathrm{n}=$ Number of items

\subsection{Technique of Data Analysis}

\section{a. Statistic Descriptive}

The purpose of statistic descriptive is to give describe about subject of research pursuant of data from group which research.

\section{b. Statistic Inferential}

Statistic inferential is technique of statistic which using for analysis sample of data and the result is gone in the effect to populations. After data collected, the researcher will determine the students score and to find out the difference score of experimental class and control class the researcher use the test

1) Test of data normality

The use of normality is to know the data normal or no, and the researcher used the formula:

$$
\mathrm{S}^{2}=\frac{n \sum f_{\mathrm{i}} x_{\mathrm{i}}-\left(\sum f_{\mathrm{i}} x_{\mathrm{i}}\right)^{2}}{n(n-1)}
$$

2) Test of homogeny

$$
F=\frac{s_{1}^{2}}{S_{2}{ }^{2}}
$$

Where:

$\mathrm{F} \quad$ : coefficient $\mathrm{F}$ test

$\mathrm{S}_{1}{ }^{2} \quad$ : largest variance

$\mathrm{S}_{2}{ }^{2} \quad$ : smallest variance

With $\mathrm{dk}=\mathrm{n}_{1}-1$ where $\alpha=0.05$

Criteria: if $\mathrm{F}_{\text {count }}<\mathrm{F}_{\text {table }}$ on $\alpha=$ so variance homogeny. 


\section{3) T-test}

After data collected, the researcher will determine the students' score and to find out the difference score of experimental class and control class the researcher use the test, as formula:

$$
t=\frac{M x-M y}{\sqrt{\left(\frac{\sum x^{2}+\sum_{y} 2}{N_{x}+N_{y}-2}\right)\left(\frac{1}{N_{x}}+\frac{1}{N_{y}}\right)}}
$$

Where:

$\mathrm{t}=\mathrm{T}-$ test

$\mathrm{X}=$ Experimental class

$\mathrm{Y} \quad=$ Control class

$\mathrm{Mx} \quad=$ Mean of experimental class

$\mathrm{X}^{2} \quad=$ Deviation score experimental

$\mathrm{Nx} \quad=$ The sample of experimental

My $\quad=$ Mean of control class

$\mathrm{Y}^{2}=$ Deviation score of control class

Ny $\quad=$ The sample of control class

\subsection{Hypothesis Testing}

Hypothesis is defined as answers while the problems formulation research. Testing hypothesis should be done in other to know whether the hypothesis is accepted or rejected. In testing hypothesis, the basic theory that the researcher use was, the hypothesis is accepted if $\mathrm{t}_{0} \leq \mathrm{t}_{\text {table }}$ or the hypothesis is rejected if $\mathrm{t}_{0} \geq \mathrm{t}_{\text {table. }}$.

\section{Results and Discussion}

\subsection{The Result of Observation}

Table 2. Students obsevation

\begin{tabular}{|c|c|c|c|}
\hline No & Aspect & Yes & No \\
\hline \multirow{4}{*}{1} & \multicolumn{3}{|l|}{ Pre-activity } \\
\hline & The students greet the teacher & $\sqrt{ }$ & \\
\hline & Give an attention to the teacher explanation & $\sqrt{ }$ & \\
\hline & $\begin{array}{l}\text { Responds the teacher question about the } \\
\text { preview material (brain storming). }\end{array}$ & $\sqrt{ }$ & \\
\hline \multirow{7}{*}{2} & \multicolumn{3}{|l|}{ Whilst activity } \\
\hline & $\begin{array}{l}\text { Students interested in the teaching learning } \\
\text { process }\end{array}$ & $\sqrt{ }$ & \\
\hline & $\begin{array}{l}\text { Students felt difficult when the teacher ask } \\
\text { them to read }\end{array}$ & $\sqrt{ }$ & \\
\hline & $\begin{array}{l}\text { Students listen the passage that read by the } \\
\text { teacher }\end{array}$ & & $\sqrt{ }$ \\
\hline & $\begin{array}{l}\text { Students have difficulties in comprehend } \\
\text { reading. }\end{array}$ & $\sqrt{ }$ & \\
\hline & $\begin{array}{l}\text { Students share their difficulties in comprehend } \\
\text { reading to the teacher }\end{array}$ & & \\
\hline & & & $\sqrt{ }$ \\
\hline
\end{tabular}




\begin{tabular}{|l|l|l|l|}
\hline \multicolumn{3}{|c|}{ Post-activity } & \\
\hline \multirow{3}{*}{3} & $\begin{array}{l}\text { The students answer the question given by the } \\
\text { English teacher. }\end{array}$ & $\sqrt{ }$ & $\sqrt{ }$ \\
\hline $\begin{array}{l}\text { The students answer the question of the } \\
\text { passage individually }\end{array}$ & $\begin{array}{l}\text { Students felt awkward to share the result of } \\
\text { their comprehension of the passage }\end{array}$ & $\sqrt{ }$ & \\
\hline & $\begin{array}{l}\text { Students listen the conclusion that given by the } \\
\text { teacher about the material. }\end{array}$ & $\sqrt{ }$ & \\
\hline & $\begin{array}{l}\text { Students felt bored in the process of learning in } \\
\text { comprehend reading. }\end{array}$ & $\sqrt{ }$ & \\
\hline
\end{tabular}

Based on the observation on the students' activity above it was clear that the students have difficulties in teaching and learning process, such as the difficulties in reading the text, comprehend reading text, the students' enthusiasm, attention and response to the teacher explanation where some students were not giving attention and response, and others.

\subsection{The Result of Test}

Table 3. The Differences Score of Pre-Test and Post-Test in Experimental Class

\begin{tabular}{cccccc}
\hline No & Name & Pre-test & Post-test & Deviation & Deviation Square \\
\hline 1 & AO & 61 & 79 & 18 & 324 \\
2 & AD & 50 & 96 & 46 & 2116 \\
3 & AS & 61 & 71 & 10 & 100 \\
4 & RS & 21 & 86 & 65 & 4225 \\
5 & RW & 61 & 86 & 25 & 625 \\
6 & F & 61 & 86 & 25 & 625 \\
7 & FM & 75 & 75 & 0 & 0 \\
8 & I & 64 & 79 & 15 & 225 \\
9 & JR & 64 & 82 & 18 & 324 \\
10 & JQ & 71 & 82 & 11 & 121 \\
11 & JK & 57 & 82 & 25 & 625 \\
12 & KN & 39 & 75 & 36 & 1296 \\
13 & M & 86 & 89 & 3 & 9 \\
14 & MF & 71 & 79 & 8 & 64 \\
15 & NRN & 82 & 86 & 4 & 16 \\
16 & NB & 25 & 75 & 50 & 2500 \\
17 & NS & 68 & 79 & 11 & 121 \\
18 & NTA & 71 & 86 & 15 & 225 \\
19 & SA & 68 & 89 & 21 & 441 \\
20 & WM & 71 & 93 & 22 & 484 \\
\hline \multicolumn{7}{c}{ Total } & 1232 & 1650 & 428 & 14466 \\
\hline & Avarage & 61 & 83 & & \\
\hline
\end{tabular}

From the data above, total score of pre-test 1232 and post-test is 1650, then mean of pre-test are 61 and post-test is 83 . 


$$
\begin{aligned}
& M_{x}=\frac{\sum x}{N_{x}} \\
= & \frac{428}{20}=21,4 \\
X^{2}= & \sum x^{2}-\frac{\left(\sum x\right)^{2}}{N_{x}} \\
= & 14466-\frac{(428)^{2}}{20} \\
= & 14466-\frac{183184}{20} \\
= & 14466-9159,2 \\
= & \mathbf{5 3 0 6 , 8}
\end{aligned}
$$

Table 4. The differences Score of Pre-Test and Post-Test in Control Class

\begin{tabular}{cccccc}
\hline No & Name & Pre-test & Post-test & Deviation & Deviation Square \\
\hline 1 & AI & 57 & 93 & 36 & 1296 \\
2 & ANK & 75 & 75 & 0 & 0 \\
3 & AW & 68 & 79 & 11 & 121 \\
4 & CA & 68 & 71 & 3 & 9 \\
5 & DS & 71 & 71 & 0 & 0 \\
6 & DJS & 54 & 71 & 17 & 289 \\
7 & HZ & 93 & 71 & 22 & 484 \\
8 & HN & 43 & 64 & 21 & 441 \\
9 & HND & 68 & 86 & 18 & 324 \\
10 & IKF & 57 & 64 & 7 & 49 \\
11 & IJ & 71 & 61 & 10 & 100 \\
12 & IA & 61 & 79 & 18 & 324 \\
13 & JR & 64 & 64 & 0 & 0 \\
14 & ML & 89 & 82 & 7 & 49 \\
15 & MS & 86 & 75 & 11 & 121 \\
16 & ML & 68 & 71 & 3 & 9 \\
17 & MR & 75 & 68 & 7 & 49 \\
18 & MBM & 96 & 96 & 0 & 0 \\
19 & NS & 68 & 71 & 3 & 9 \\
20 & NH & 61 & 68 & 7 & 49 \\
\hline \multicolumn{7}{c}{ Total } & 1393 & 1482 & 201 & 3723 \\
\hline
\end{tabular}

From the data above, total score of pre-test 1393 and post-test is 1482, then mean of pre-test are 70 and post-test is 74 . 


$$
\begin{aligned}
M_{y}=\frac{\sum x}{N_{x}} \\
=\frac{201}{20}=\mathbf{1 0 , 0 5} \\
Y^{2}=\sum x^{2}-\frac{\left(\sum x\right)^{2}}{N_{x}} \\
=3723-\frac{(201)^{2}}{20} \\
=3723-\frac{40401}{20} \\
=3723-2020,05 \\
=\mathbf{1 7 0 2 , 2 5}
\end{aligned}
$$

Based in data analysis above, it is obtained that:

$\begin{array}{ll}\mathrm{M}_{\mathrm{x}} & : 21,4 \\ \mathrm{X}^{2} & : 5306,8 \\ \mathrm{~N}_{\mathrm{x}} & : 20 \\ \mathrm{M}_{\mathrm{y}} & : 10,05 \\ \mathrm{Y}^{2} & : 1702,25 \\ \mathrm{~N}_{\mathrm{y}} & : 20\end{array}$

The formula for computing the T-test is as follow:

$$
\begin{aligned}
t & =\frac{M x-M y}{\sqrt{\left(\frac{\sum x^{2}+\sum_{y} 2}{N_{x}+N_{y}-2}\right)\left(\frac{1}{N_{x}}+\frac{1}{N_{y}}\right)}} \\
t & =\frac{M x-M y}{\sqrt{\left(\frac{5306,8+1702,25}{20+20-2}\right)\left(\frac{1}{20}+\frac{1}{20}\right)}} \\
t & =\frac{21,4-10,05}{\sqrt{\left(\frac{3604,55}{20+20-2}\right)\left(\frac{1}{20}+\frac{1}{20}\right)}} \\
& =\frac{21,4-10,05}{\sqrt{\left(\frac{3604,55}{38}\right)\left(\frac{2}{20}\right)}} \\
= & \frac{21,4-10,05}{\sqrt{(94,9)(0,1)}} \\
& =\frac{11,35}{\sqrt{9,5}}
\end{aligned}
$$




$$
\begin{aligned}
& =\frac{11,35}{3,08} \\
& =3,68
\end{aligned}
$$

Based on the researcher observation during the process of teaching in reading through SCROL strategy, the researcher found the result of research that SCROL strategy can give significantly affect to increase students' reading comprehension.

\subsection{Testing Hypothesis}

Testing hypothesis should be done in order to know whether the hypothesis is accepted or rejected. Hypothesis is temporary answer from of study was made in question form. The basic theory that the researcher used was the hypothesis is accepted if $t_{\text {score }}>t_{\text {table }}$. To find the degree of freedom (df) as follows:

$$
\begin{aligned}
D f & =n_{1}+n_{2}-2 \\
& =20+20-2 \\
& =38 \\
T_{\text {table }} & =t(\text { ax } n 1+n 2-2) \\
& =t(0,05)(38) \\
& =1,9
\end{aligned}
$$

Where:

Df $=$ Degree of freedom

$\mathrm{N}_{\mathrm{x}} \quad=$ The sample of experimental class

$\mathrm{N}_{\mathrm{y}} \quad=$ The sample of control class

From the result above:

$$
\begin{array}{ll}
\mathrm{T}_{\text {score }} & =3,8 \\
\mathrm{~T}_{\text {table }} & =1,9
\end{array}
$$

Therefore, $t_{\text {score }}>t_{\text {table }}(0,05)$ with degree of freedom $(\mathrm{df})=38$. It can be concluded that $t_{\text {score }}$ is higher that $t_{\text {table }}(3,8>1,9)$. Based on calculation of $t$-test, where the value $t_{\text {score }}$ higher than $t_{\text {table }} 1,9(0,05)$. It showed that the research of hypothesis $\left(\mathrm{H}_{\mathrm{a}}\right)$ is accepted and null hypothesis $\left(\mathrm{H}_{0}\right)$ is rejected. It means that using SCROL strategy is significantly affect to increase student's reading comprehension of descriptive text at tenth grade of MAN 1 Takengon.

\section{Conclusion}

Based on the result of this research SCROL strategy is significantly affect to increase students' reading comprehension. It can be proved from the students' score which better by using SCROL strategy than the conventional method used in teaching reading. Based on the result of pre-test showed that the total score of the students in experimental class in reading test was 1232 from 20 students and the mean was 61 . In post-test was 1650 and mean was 83. Meanwhile, in the control class at pre-test the total score was 1393 and the mean was 70 . In the post test was 1480 with mean was 74 . Based on calculation of t-test, where the value of tscore 3,8 is higher than table 1,9 at the level significance 0,05 . It shows that the hypothesis (Ha) is accepted and the research hypothesis (Ho) is rejected. It means that the using of SCROL strategy is significantly affect to increase students' reading comprehension of descriptive at Tenth grade of MAN 1 Takengon. 


\section{References}

Anderson, M and Anderson (2003) Text Types in English. Australia: Macmilan Education Australia

Arikunto, Suharsimi (2006) Prosedur Penelitian Suatu Pendekatan Praktik. Jakarta: PT Rineka Cipta

Ary, Donald (2002) Introduction to Research in Education. USA: Wadsworth Group A Division of Thompson Learning, Inc.

Brindley, Susan (2003). Teaching English. London: Routledge

Douglass, H. Brown (2001) Teaching by Principles An Interactive Approach to Language Pedagody. San Francisco: Longman

Drs. Bukhari, M.Pd (2010) Keterampilan berbahasa membaca dan Menulis. Banda Aceh: Pena

Grant, R. 2000. Strategic Training for Using Text Heading to Improve Students' Processing of Content. Journal of Reading, 36 (6), 482-488.

Harmer, Jeremy (2000). The practice of English Language Teaching. Longman: United Kingdom

M. F Patel and Praven M Jain (2008). English language Teaching: Method, Tools and Technique. Jaipur: Sunrise Publisher

Nunan, David (1989). Designing Task of Communicative Classroom. United England: Cambridge University Press

Pardiyono (2007), Pasti Bisa. Teaching Genre-based Writing. Yogyakarta: CV. Andi Offset

Reid, R., \& Torri O.L. 2006. Strategy Instruction for Students with Learning Disabilities. New York: The Guilford Press, A Division of Guilford Publications, Inc.

Rivers, M \& Temperley, S. (1978) A practical Guide to the Teaching of English as A Second Language or Foreign Language. Oxford: Oxford University Press

Sugiyono (2011) Metode Penelitian Kuantitative danKualitatif dan R\&D. Bandung: Alfabeta

T, Emirfan Mulyati (2011) Buku Brlian Bahasa Inggris. Yogyakarta: Javalitera

Vaughn, Sharon and Linan, Sylvia Thompson (2004). Research-Based Methods of Reading Instruction, USA: ASCD

Westwood, Peter (2001) Reading and learning Dificulties; Approach to Teaching and Assessment Australia: Acer Press

Widdowson, H (1979). The Process and Purpose of Reading Explorations in Applied Linguistics. Oxford: Oxford University Press.

W. John Creswell (2002) Research Design Quantitative and Mixed Methods Approaches. USA: SAGE Publications

Yudantoro, Elang (2010) Rangkuman bahasa Inggris. Jakarta: Gagas Media 